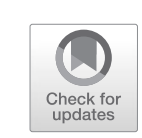

\title{
Cultural Transmission in Slovak Mountain Regions: Local Knowledge as Symbolic Argumentation
}

\author{
Ivan Murin
}

\section{INTRODUCTION}

Many traditional cultures have found their way to managing their surrounding environment. Over many generations, traditional cultures and local communities have learned that having fish in the rivers and wildlife in the forests depends on not cutting down all the trees and not wiping out the fish stock, but keeping it at a viable level to maintain ecological balance. Through their ongoing interaction with the environment and the ways they talk about and with their lands and the species within them, traditional cultures have developed cultural strategies for resource management (see Kugo, chapter "Community Voices, Practices, and Memories in Environmental Communication: Iliamna Lake Yup'ik Place Names,

\section{Murin (ه)}

Department of Social Studies and Ethnology, Matej Bel University, Banská Bystrica, Slovakia

e-mail: ivan.murin@umb.sk

(C) The Author(s) 2022

A. Sjölander-Lindqvist et al. (eds.), Anthropological Perspectives on Environmental Communication, Palgrave Studies in Anthropology of Sustainability, https://doi.org/10.1007/978-3-030-78040-1_4 
Alaska" of this book). Such culturally defined knowledge includes and builds upon a diverse set of practices, discourses, and ideas, which are shared across generations. This knowledge provides an important foundation for cultural identity at local, regional, and even national levels, but is also a kind of knowledge that is important for sustainability.

Traditional systems of land use, for example, are an important foundation for community viability (Berkes \& Folke, 2002), and should therefore be harnessed, as this knowledge can benefit the management of common property. Maintaining Traditional Ecological Knowledge (TEK) is, however, dependent on both the ability of local communities to uphold practices and learn from their performance, and the verbal and intergenerational sharing of stories and narratives about local life, community resources, knowledge, and experiences (Anderson, 2015).

This chapter brings us to the remote Mountainside Settlements of Central Slovakia (MSCS), where the change and abandonment of traditional land-use practices, due to outmigration to urban centers and aging rural populations, has implications for the ability of the $\operatorname{Vrchar}^{1}$ culture to sustain social ties, manage community-based agricultural resources, and protect the cultural landscape. Outmigration has led to depopulation and consequently fewer people who farm the lands of the MSCS. Subsequently, the abandonment of traditional ways of managing land and local resources has led to fewer opportunities to share knowledge and establish a common reference to the environment, which we know come into being through concerted, fortuitous, embodied, and lived practices (Sjölander-Lindqvist \& Sandström, 2019).

Depopulation of less productive, remote, and mountainous regions and areas is a trend well known to many countries around the world. In Europe and beyond, recent decades have seen a general demographic phenomenon of the depopulation of peripheral areas, especially those characterized by rural traditions (MacDonald et al., 2000), and migration to industrial centers (Feranec et al., 2010). In such a context, the loss of Traditional Ecological Knowledge may be an obvious outcome. Some of the negative consequences relate to the reduced diversity of the land-use mosaic and consequent landscape homogeneity (Navarro \& Pereira, 2012). With the gradual disappearance of local cultures, society loses diversity and cases of adaptation to local circumstances that we can learn from for the

\footnotetext{
'Slovak, sing. vrchár, pl. vrchári, lit. "mountainers," loosely equivalent to "mountainfolk" or even "hillbillies," given the term's historically pejorative connotation.
} 
development of sustainable solutions. Owing to the relationships between different environments, the constantly evolving changes to the ecosystem, and the ability of a local community to manage local resources, the generational exchange of experiences, insights, and knowledge presents a challenge to contemporary society.

\section{Traditional Ecological Knowledge as an Adaptation Process}

Traditional Ecological Knowledge (TEK) is experience that has been acquired from direct human interaction with the environment. It can be thought of as the result of people in natural environments who, through their engagement with the environment and the species within it, have found ways to maintain their livelihoods and thereby discover and develop paths of adaptation (Berkes, 1993; Colloff et al., 2020). In rural areas, TEK is particularly important for "the regulation and balance of exploitative pressures that permit an ecosystem to maintain stability and regenerative capacity" (Ruddle, 1993, p. 17). There are a number of examples in the anthropological literature which show that knowledge is situated and culture-specific. Particularly relevant to the present case study are examples of the development of mountain grazing in similar mountainous conditions in Europe, namely in the Pyrenees (Fernández-Giménez \& Fillat Est, 2012), Alps (Gilck \& Poschlod, 2019), and Carpathians (Novák et al., 2014). Gradually, geographically distinctive grazing and farming techniques have developed and adapted in various ways to ensure the sustainability of ecosystems and human settlements.

TEK is experience and knowledge, but it is also an intellectual activity found in a wide range of social, cultural, and environmental contexts (Folke, 2004; Gómez-Baggethun \& Reyes-García, 2019). The persistence of this knowledge is dependent on it being shared across generations (Cocks, 2006; Ruddle, 1993) according to certain structural and processual principles (Cocks, 2006; Ruddle, 1993) and based on the constant and rigorous perception of changes in society and environment (Colloff et al., 2020). The success of these socio-cultural processes can be assessed in the extent to which individual communities and cultures have managed to co-adapt to their environments (Stoffle et al., 2003). A precondition for successful co-adaptation is the ability of the individual community/culture to, continuously and over time, balance and develop their actions in 
response to biophysical changes and ecological processes as well those changes brought on by societal processes (Gardner, 2017), but it also requires a continuous flow of knowledge between community members (Cocks, 2006; Ruddle, 1993). During the transmission of knowledge, customary ways of doing things are a core institution through which traditional ecological and environmental knowledge is given and received in a social world and in analogy with "the biological-physical world with which it overlaps" (Ruddle, 1993, p. 19). This knowledge is, to borrow from Ruddle (1993), a "key dialectic of society," as traditionally and culturally grounded knowledge is about being-socially, culturally, and ecologically - in the world. From this perspective, TEK is a concept that captures both the everyday social reality and our continuous reproduction of everyday life (Berger \& Luckmann, 1966).

Ultimately, the persistence of TEK is dependent on continuous transmission over generations. Turning our eyes to contemporary life, in Slovakia, Europe more broadly, and other parts of the world, we find society struggling with the challenges of globalization, urbanization, digitalization, individualization, and demographic change. These have far-reaching consequences for human well-being, which requires the integration of traditional knowledge to enable the development of sustainable solutions to the key environmental threats of climate change, land degradation, and loss of biodiversity (IPBES, 2019). The long-term trend of aging rural populations is in itself worrying, since it, together with urbanization, increases the rate of depopulation, reflecting in part the tendency of young people to leave the countryside to find employment and another kind of life in urban and metropolitan areas throughout Europe (The Permanent European Conference for the Study of the Rural Landscape). In addition, rural areas in Europe are experiencing a growing share of young unemployed people (aged 18-24) who do not continue their education past the secondary level (Eurostat, 2019). These developments have consequences for the capacity of the rural communities to adapt to changing circumstances (Lieskovský et al., 2015). While it has long been assumed that the level of economic development is crucial to a society's capacity to adapt to climate change, evidence points toward the conclusion that societies that depend "more on experience, knowledge and [...] weather-sensitive resources" are better at finding solutions to environmental risks (Adger \& Vincent, 2005).

Anthropological theory on how people and cultures adapt to different circumstances (Steward, 1955; McDonnell \& Pickett, 1993; Ruddle, 
1993; Stoffle et al., 2013) is important with respect to TEK transmission, together with anthropological knowledge on how we, as human beings, create a sense of belonging to particular places and landscapes as bounded spaces for thought and action (Appadurai, 1986; Ingold, 2000; SjölanderLindqvist \& Sandström, 2019; Kugo, chapter "Community Voices, Practices, and Memories in Environmental Communication: Iliamna Lake Yup'ik Place Names, Alaska" of this book; Sjölander-Lindqvist, chapter "Arsenic Fields: Community Understandings of Risk, Place, and Landscape"; Stoffle, chapter "Living Stone Bridges: Epistemological Divides in Heritage Environmental Communication"; Van Vlack, chapter "Dancing with Lava: Indigenous Interactions with an Active Volcano in Arizona"). These two areas of theory bring important perspectives to the role of TEK in co-adaptation, but how we transmit information through symbolic references to the environment is also important in terms of environmental communication. Through knowledge of partial adaptations, the competency for global sustainability policy increases. From an anthropological standpoint, cultural adaptations are considered more important than technological adaptations. This can be justified by the fact that the creation of symbolic references to the environment, classifications, and taxonomy is a long-term process, a consequence of the daily contact of generations of people with the environment. The cultural ways of coadaptation are the basis for the moral order of societies; they are explained in narratives and transmitted in symbols.

\section{Methods}

In 2005, local action groups contacted Vrchári from the northern Malohont region. These people represented a generation of Vrchári who, at the end of the twentieth century, had the lands of their ancestors returned to them. They came from different regions of Slovakia and did not have direct-contact experience with the environment that their ancestors had inhabited. They were interested in revitalizing their ancestors' environment, but lacked the necessary knowledge of the practices in which their ancestors had worked in this environment.

People in the local communities invited anthropologists to (1) conduct archival research into Vrchár culture, (2) compile an inventory of the current state of Vrchár culture, and (3) incorporate the local TEK into applications for environmental sustainability grants. The archival research provided sufficient historical findings of TEK workers in northern 
Malohont. In 2010-2017, the anthropologists selected the Northern Malohont Research Area as a site for research into the continuity and discontinuity of cultural transmission. The real, manifest, as well as latent contents of the lived culture's TEK were investigated by inventorying (Horton et al., 2017) the area. Via observations and interviews, the predominant modes of cultural transmission were identified (LeCompte \& Schensul, 2013). With respect to the revitalization possibilities, a fourth action was also taken: creating a TEK transmission model (Table 1 ) for the new generation of Vrchári with a view toward sustainability for subsequent generations.

The grant application component focused on developing a local theory of the current population of Vrchári and on their new strategies of communication with the public. The applicants and partners are

Table 1 Generalized model of TEK(Babai \& Molnár, 2014,p. 126)-Traditional treatments of hay meadows (Al-A8) and pastures (Bl-B4) by older generations of Vrchári in northern Malohont, Slovakia

\begin{tabular}{|c|c|c|c|c|c|c|c|c|c|c|c|}
\hline Meadow/pasture & $\mathrm{Feb}$ & Mar & $A p r$ & May & Jun & $J u l$ & Aug & Sept & $O c t$ & Nov & $\begin{array}{l}\text { Affected area } \\
\text { (\% of total) }\end{array}$ \\
\hline Ala-mowing & & & & $\mathrm{x}$ & & $\mathrm{x}$ & & $(\mathrm{x})$ & & & $>40$ \\
\hline $\begin{array}{l}\text { Alb-mowing and } \\
\text { regrowing }\end{array}$ & & & & $\mathrm{x}$ & & & & & & & $>50$ \\
\hline A2-clearing & & $\mathrm{x}$ & & & & & & & & & $>60$ \\
\hline $\begin{array}{l}\text { A3-hayseed } \\
\text { scattering }\end{array}$ & & & & & $\mathrm{x}$ & & & & & & $10-15$ \\
\hline $\begin{array}{l}\text { A4-oversowing } \\
\text { with Onobrychis }\end{array}$ & & $\mathrm{x}$ & & & & & & & & & $0.1-0.5$ \\
\hline $\begin{array}{l}\text { A5-extensive } \\
\text { manuring }\end{array}$ & $\mathrm{x}$ & & & & & & & & & & $25-30$ \\
\hline A6-weeding & & & & & & & & $\mathrm{x}$ & & & $30-40$ \\
\hline $\begin{array}{l}\text { A7-moss } \\
\text { suppression }\end{array}$ & $\mathrm{x}$ & & & & $\mathrm{x}$ & & & & & & $0.1-0.5$ \\
\hline $\begin{array}{l}\text { A8-marsh } \\
\text { draining }\end{array}$ & & & $\mathrm{x}$ & & & & & & & & $0.1-0.3$ \\
\hline $\mathrm{Bl}$-grazing & & & & $(\mathrm{x})$ & $\mathrm{x}$ & $\mathrm{x}$ & $\mathrm{x}$ & $\mathrm{x}$ & $\mathrm{x}$ & $(\mathrm{x})$ & $>95$ \\
\hline $\begin{array}{l}\text { B2-pasture } \\
\text { clearing }\end{array}$ & $\mathrm{x}$ & $\mathrm{x}$ & & & $(\mathrm{x})$ & $\mathrm{x}$ & & & & & $70-75$ \\
\hline B3-fence repair & $\mathrm{x}$ & & & & & & $\mathrm{x}$ & & $\mathrm{x}$ & & $>95$ \\
\hline $\begin{array}{l}\text { B4-burning to } \\
\text { prevent Nardus }\end{array}$ & $\mathrm{x}$ & $(\mathrm{x})$ & & & & & & & & & $5-10$ \\
\hline
\end{tabular}

${ }^{a}$ In autumn cattle graze on aftermath 
multi-stakeholders, mainly government representatives and advocates of intensive forest management and intensive agricultural development. Symbolic arguments (Depoe, 2007; Cox, 2006, 2015) of continuity and discontinuity of the MSCS are gradually gaining general support.

\section{Mountains AND VRCHÁRI}

Historical geographers consider the MSCS to be the best preserved type of historical structure of traditionally farmed agricultural landscapes in Slovakia. In ethnography, the displaced and dispersed forms of MSCS are called lazy, vrchy, kopanice, śtále, and rale. Their main identifying characteristic is dispersed (family) settlements (DSs). The culture that has emerged in this way is called Vrchár culture (prchárska kultura). In Slovak, its bearers are called vrchári, laznici, or kopaničiari. DSs are an autonomous demonstration of Vrchár culture and socioeconomic activity, preconditioned by specific natural and historical conditions. In the text, we will call them by their Slovak name, Vrchári, as used in ethnological studies (Ethnographic Institute of the Slovak Academy of Sciences, 1994). Anthropologically they are considered an ethnographic group with their own mountain-adapted culture. The map in Fig. 1 displays the Vrchár culture in the Slovak Ore Mountains (Slovenské rudoborie) and Krupina Plain (Krupinská planina) as of 2018 (92 municipalities over an area of $\left.2258 \mathrm{~km}^{2}\right)$.

The emergence of Vrchár culture is related to several attempts to settle the mountainous areas of Central Slovakia from the twelfth to the nineteenth centuries. Gradually, more multigenerational homesteads were established on the outer edges of the valley villages. The emergence of almost continually inhabited landscape areas was related to the internal migration within the mountain and foothill areas of Slovakia which took place in the sixteenth-nineteenth centuries (Huba, 1997). The Vrchári adapted to the mountain environment via mountain farming and other complementary socioeconomic activities. The Vrchári gradually developed a specific type of land exploitation, a type of settlement, and an intrinsically identifiable culture. Their origin is characterized by (1) efforts to use the land of the forest and ecumene more efficiently on the one hand, and on the other, by (2) the stimulating effect of human adaptation on population growth. Settlement waves were the directly connected to the relative overpopulation of Slovakia's historical ecumene. The establishment of DSs also had a number of sub-causes, such as higher soil cultivability in the case 


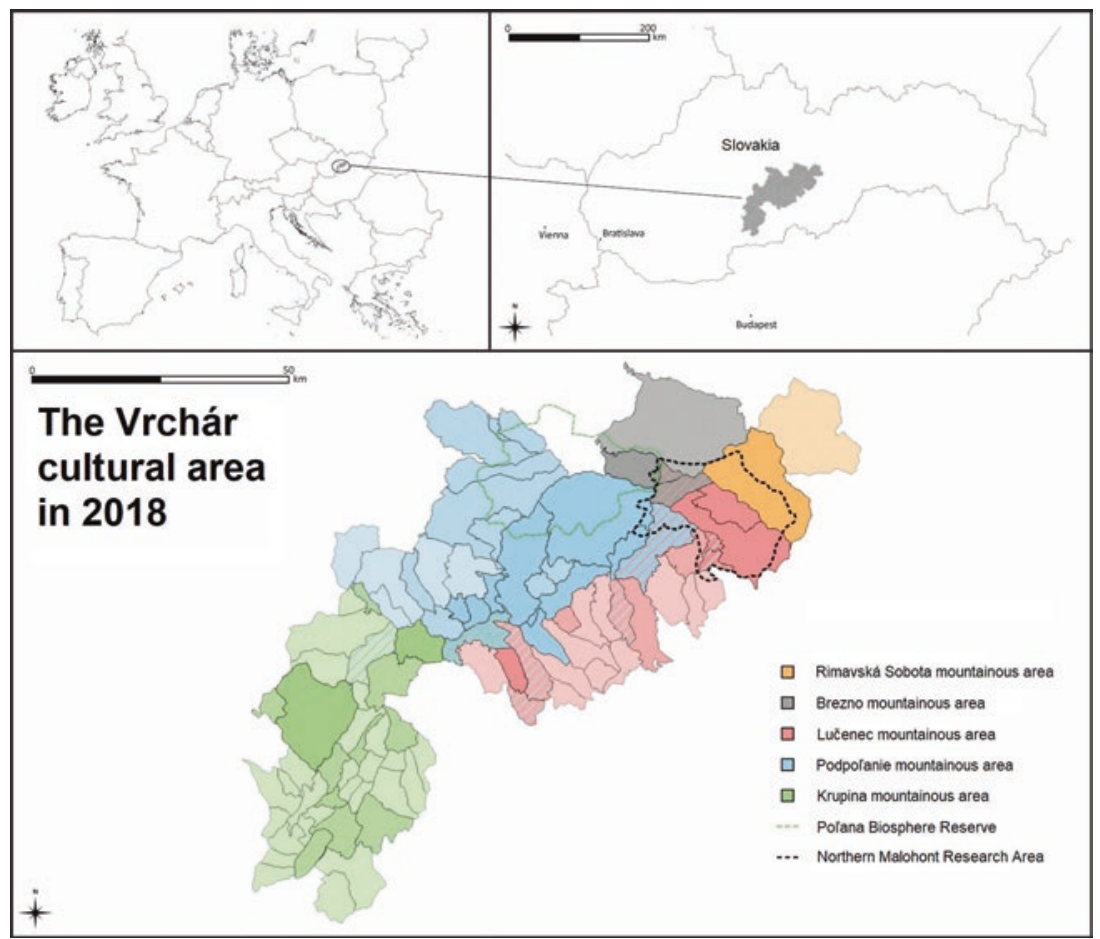

Fig. 1 The Vrchár cultural area in 2018, shaded according to the occurrence of significant cultural features (Ethnographic Institute of the Slovak Academy of Sciences, 1994). The main areas of Vrchár culture (darkest areas) originated outside dense settlements from the seventeenth to the nineteenth centuries. Via young internal migration in the nineteenth century, the DSs also spread to adjacent areas (medium-dark areas). The lightest areas are those DSs that originated in the twentieth century and later lost the original function of multigenerational homesteads. Cultural overlaps of the sub-regions are marked by hatching. (This map was created by Michal Filadelfi and Ivan Murin in QGIS (free version https:/ / qgis.org/en/site/) and Adobe, license no. CE08041211, and is used with its creators' permission)

of permanent settlement of remote parts of the villages, relative abundance of free land, lower taxes, search for refuge from war, and so on (Petrovič, 2006). 
A multi-member three-generation family became the basis for the sustainability of the emerging mountainside settlements. Its numerosity directly depended on the ability to process the soil. However, the relationships between the settlements were most affected by the crucial reciprocity between the inhabitants. This was characterized by extensive forms of interchange between families linked by closer ties. This led to internal integration within Vrchár society, resulting in a culture that was cohesive and set apart from urban society. Social norms and cultural values were created independently of the populations of the agrarian lowlands and towns. There was a prevalence of direct-contact generational transfer of knowledge and its synchronization with changes in the environment (Murin \& Kandert, 2018).

The greatest expansion of Vrchár culture can be identified in the first half of the twentieth century, ${ }^{2}$ triggered by the First Land Reform of Slovakia at the beginning of the twentieth century. A large land property was allocated to the Vrchári, by which the area occupied by DSs expanded (Špulerová et al., 2016). During this period, the MSCS had high structural diversity and therefore ecological stability. Due to their heterogeneity of shape and area, and varied cultivation of culturally characteristic crop varieties, the model of DSs was created to describe the MSCS. It was during this period that the cultural character of the Vrchári as an ethnographic group took shape.

The development in the Vrchár settlement area in the second half of the twentieth century was mainly associated with extensive industrialization. This constituted the first violation of the Vrchár generational structure (Petrovič, 2006). The increasing individualization of activities and, in particular, the compulsory employment of Vrchári in state-owned or largescale agribusinesses and the metals industry was the reason for the first significant departure of the young generation. This change was adopted

${ }^{2}$ The first mentions of the number of villages with dispersed settlements come from Janšák (1929), who identified 132 villages with 2176 parts. In 1961, Slovakia was home to 166 villages with dispersed settlements with 2899 dispersed parts on an area of $4640 \mathrm{~km}^{2}$, which made up $9.46 \%$ of Slovakia. The increase in the number of villages and dispersed settlements is probably the result of inaccurate census-taking in 1929 and not the establishment of new villages. At present, the emergence of new villages with dispersed settlements is unlikely, even unimaginable, given the lack of new farmland. Originally, dispersed settlements displayed a prevailing tendency of decline and extinction. The basic function of the dispersed settlements was soil cultivation in marginal areas. In recent years these areas have been in decline (Mládek et al., 2006). 
by the Vrchár community, giving rise to a new model of the Vrchár as "iron-farmer" (kovorolnik) (Kandert, 2007).

Gradually, however, state pressure for Vrchári to leave the MSCS grew stronger. The totalitarian ideology of Communist Czechoslovakia justified the decline of DSs as industrial and civilizational progress. Two other state/political decisions in the second half of the twentieth century significantly marked the development of DSs and the culture of the Vrchári. The strategy of intensifying agriculture and forestry led to the consolidation of the disconnected, scattered homesteads. This also extended to terrain, water management, and other measures to increase soil fertility and improve economic returns. ${ }^{3}$ State-managed collectivization and cooperative farming led to the extinction of many DSs and the overall homogenization of the countryside (Lieskovský et al., 2015). Following voluntary resettlement in the 1950s and the subsequent state-initiated displacement of Vrchári in the 1970s, a large part of the MSCS was left abandoned. At the beginning of the 1980s, Czechoslovak ethnologist Soňa Švecová expressed the opinion that the DSs would either go extinct as a consequence of Slovakia's new socioeconomic situation or exist in other (recreational) conditions and functions (Švecová, 1975).

After 1990, the displacement of the Vrchári was partially halted and the landscape structure of MSCS became more diversified. There was some generational rejuvenation of Vrchári and loss of landscape macrostructures. This was caused by a change in the land ownership structure when the land was returned to its original owners or their heirs. ${ }^{4}$

\section{Land Abandonment as Loss of Cultural and Natural Diversity}

At present, DSs rarely fulfill their primary function of providing permanent residence to multigenerational families. The communities of the Vrchári are not territorially concentrated, and their social ties have been lost. Their main focus is on cottage industry and productive farming

\footnotetext{
${ }^{3}$ Land modification during the period of socialization of Slovak agriculture was carried out in two stages. The first stage was implemented in 1955 via Regulation No. 47/1955 Coll. The second stage of land consolidation was guided by Regulation No. 12 064/1977 in 1977.

${ }^{4}$ Act No. 229/1991 Coll. on the Modification of Ownership Relations to Land and Other Agricultural Property abolished all Communist-era land expropriations and restored full ownership to the original owners.
} 
(Priečko, 2015). Cultivation is mostly limited to maintaining permanent grassland near the houses, especially for aesthetic purposes, or fruit orchards. More sustainable are those areas which have retained a diversity of resources and income. This is mainly due to residues from mountain farming and the provision of ecosystem services (Sandhu \& Wratten, 2013). However, the young generations of Vrchári lack the continuous TEK they would need in order to be successful.

A large part of the land is only sporadically used, exhibiting ecological succession and overgrown by woods and shrubs (Kanianska, Kizeková, Nováček, \& Zeman, 2014). The original expectations of mid-twentiethcentury central forest planners that the intensification of forest cultivation would create new livelihood opportunities for Vrchári have not been fulfilled. Planting forest for cultivation can only feed a few workers skilled in forestry. Wood is not processed locally, but transported to industrial centers.

At present, the significant risk to the Vrchári's environment and population is global warming. It is causing rapid extinction of the uninhabited forest plantations and abandonment of the countryside by the last Vrchári (Lieskovský et al., 2015), as you can see in Figs. 2 and 3. In the foothills, it is mainly farmed land and permanent grassland that are being lost. ${ }^{5}$ In this way the epicenters of species diversity (including the human population) and cultural diversity are disappearing. ${ }^{6}$ The Vrchári's mowed meadows and extensive pastures are among the richest plant communities in this area. However, their maintenance is not possible without regular care. A major problem is the expansion of high grasses, which push out other herbaceous vegetation. This vegetation is the most valuable trait of herbaceous grassland communities, and it is also lost to colonization by woods.

In 1992, the Slovak Republic returned the land in the northern Malohont region to the previous Vrchár landowners from before the Communist era. For anthropologists, this created an opportunity to explore the re-adaptation of new generations to the environment of their ancestors. Such research has become the basis of cooperation between

\footnotetext{
${ }^{5}$ The migratory front of the ravines grows at a rate of about $1.7 \mathrm{~m}$ per year. Since the countryside was abandoned and mowing was discontinued, the edge of the woodlands has increased by more than $80 \mathrm{~m}$ in about 50 years.

${ }^{6}$ According to a comparison of historical aerial photographs over the last decade, we know that the rate of change is not constant, but accelerating. Clonal species grow in the herbaceous layer, and the grasslands are ceasing to be a part of the landscape image of the DSs.
} 

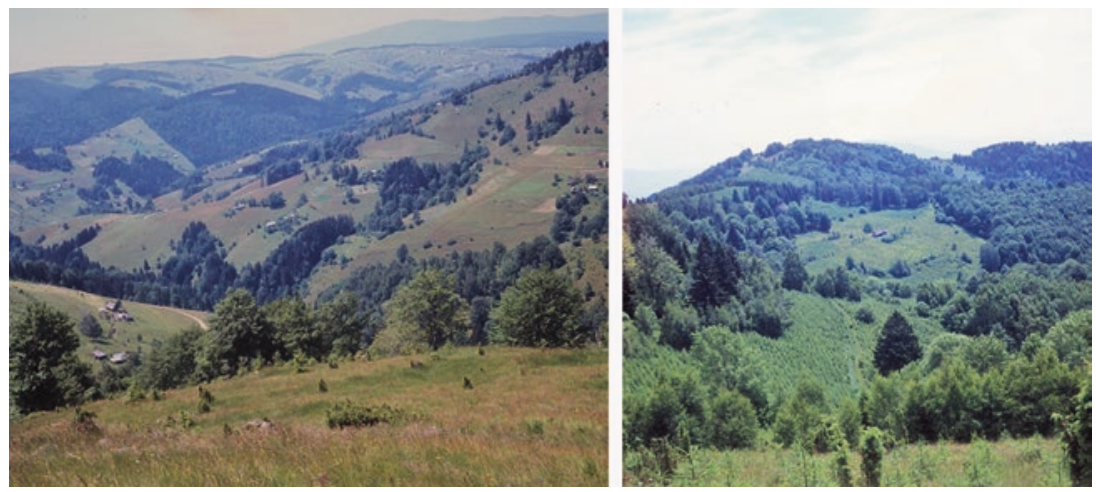

Figs. 2 and 3 Lived-in (Fig. 2, left) and abandoned (Fig. 3, right) DSs in the 1970s and 1980s, and planted monoculture of common spruce (Picea abies). (These images used with permission of the Slovak Academy of Sciences, Institute of Ethnology and Social Anthropology, 1977, No. AD008941)

researchers and Vrchári in the application of TEK arguments to environmental communication.

\section{Anthropological Arguments for the Continuity of Generational Transmission}

When explaining the patterns of culture transfer, we often point to parallels with the equivalents of general population evolution. With human populations, we are looking for a common culture origin, selection, and adaptation processes for the constant change, stabilization, and subsequent variation of culture in its various reproductions. Transmission of culture can be considered to be the distribution of culturally specific information bound to the local community (Fig. 4) which is transmitted through various transmission modes among its members (Tindall, 1976; Cavalli-Sforza \& Feldman, 1981). We take this to mean that this information has a limited scope and links to local contexts. It originates in wellknown sources, follows a consistent dissemination algorithm, and is applied in similar community structures and in similar historical contexts. Transmission in a scattered environment is perceived thus: the more closely people's lives are intertwined and the longer they share similar 
Intergenerational transmission of Vrchár TEK

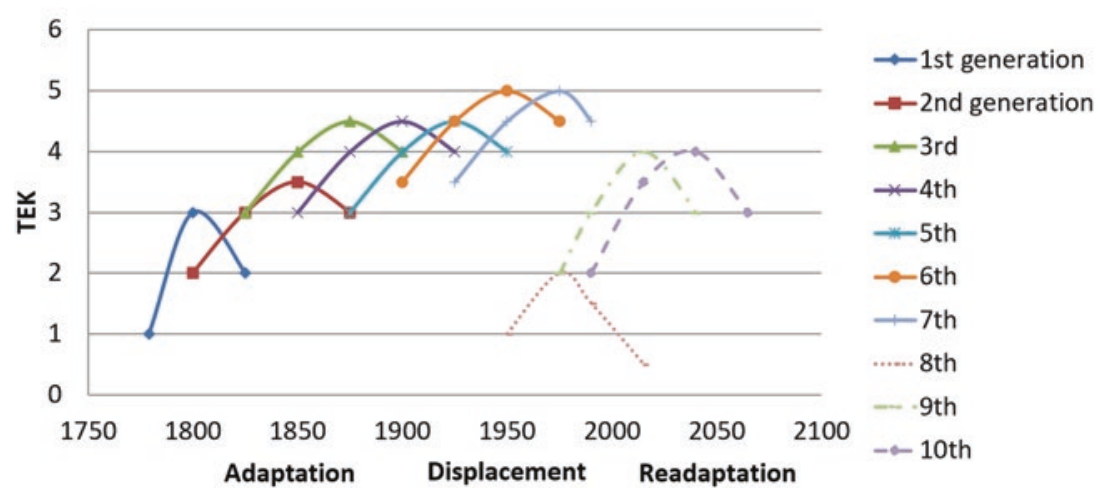

Fig. 4 The six-function adaptation scheme (Stoffle et al., 2003) and discontinuity of Vrchár culture. (Created by Ivan Murin)

contexts of environment and historicity, the higher the number of common cultural elements they display.

\section{Argument 1: The Floating TEK Gap}

Northern Malohont was forested 50 years ago, and nowadays it is covered by spruce forest plantations. Due to global warming, it is endangered by wind, drought, and ligniperdous insects (Ips typographus). In the past, working in the woods was one of the seasonal jobs of the Vrchári. At present it is their only work. The most common images of DSs are family homes transformed into garages of forest mechanization. The transformation of the last Vrchári into loggers was generally caused by a massive rise of natural disasters in large forest plantations (Gömöry et al., 2006). Consequently, young generations are not abundantly integrated in alternative survival activities in DSs.

When I left for the city, I knew how to do everything I touched. What I didn't know, I learned quickly. For life in the mountains, you needed such people. The young ones in the mountains now are helpless. They can only do one job, they didn't have the opportunity to learn everything, so they're poor. (Vrchár male, 60 years, interview, 2018, trans. Ivan Murin) 


\section{Argument 2: The Three-Generation Model Family}

The everyday interaction of all family members with the environment is the basis of TEK in use. These have their own rhythm. Disturbing the rhythm threatens the entire circle needed for sustainable survival.

\section{The Example of the Ilčík Family}

The Ilčík family initiated a gathering involving presentations of TEK (Lindenfeld et al., 2012) and linking of knowledge in the form of an event known as an "ox-team race" (volské zápraby). ${ }^{7}$ They reasoned that the event was necessary to maintain the rhythm of family activities. A sustainable family model has existed for 50 years. The family house and homestead must be inhabited by three families, namely the family of the father and the families of his two children. In addition to working in the field, they must also have jobs that do not require more than eight hours outside the homestead. Single members may leave for work for longer. Men and members of the youngest, still single generation must be able to commute to towns. Married women and some single young women may be seasonally employed outside the DS.

To stay here in the hills, we have to be a big family. Every hand and every mind is missed when it's gone. We all have to know what we have to do every day. Not everyone gets used to it and learns. When the old ones die, we won't know how to go on. When the young ones leave, there won't be anyone left to work. (Vrchár female, 82 years, interview, 2018, trans. Ivan Murin)

Any disturbance of the family rhythm threatens Vrchár culture. Each loss of knowledge must be replaced by something from the external environment. Each time an activity is isolated from its context, there is a loss of the complexity of TEK.

${ }^{7}$ Originally denoting an actual ox-team race, volské záprahy now refers to a festive event involving, among other activities, a stylized procession of a team of oxen. This newfound tradition has led to a modest revival of ox husbandry and the oxen's status among Vrchári, with some even keeping them as work animals once again. 


\section{Argument 3: Cattle Farming as a Symbol of Identity, INTEGRITY, AND LIVELIHOOD}

The DSs provide conditions for family cattle breeding. The number of cattle kept during the winter is directly related to the sufficiency of the stocks of fodder, especially hay. Mowing, drying, and storing hay is one of the most important activities in the farmer's economic year, and the whole family takes part. Higher-quality meadows are usually mowed twice a year. An important piece of TEK is the maintenance of meadows: clearing them, collecting stones in the spring and after mowing, and fertilization. The process also includes transporting the dried hay, and the TEK of conveying the hay from the steep slopes to the DSs with a team of oxen has been preserved.

Grazing, milk and meat production, and the oxen yoke became the symbols of the world of the Vrchári, representing their source of income and raw ingredients for food preparation. Prosperity was associated with seasonal cattle for sale and high cow's milk production. Farming with three to four head of livestock requires intensive relationships with five to six families with the same ways of husbandry. Collaboration then creates synchronic activities that are not substitutable.

We need to keep a few neighboring families in order to stay alive here. They must have four to five cows, like us, and at least six family members to take care of them. We don't have grandparents who could stay with the cattle while we go to town. Common grazing saves us all time. After some young people left for the towns, we had to abandon the common pasture. The new generation hasn't been able to learn fast and effective ways of building fences in the rugged terrain. (Vrchár male, 40 years, interview, 2018, trans. Ivan Murin)

Each Vrchár cultural community has symbols that represent their identity and mutual integrity. For the Northern Malohont Research Area, it is cattle. The team of oxen is historically the most important means of transport there (Fig. 5). This was reflected in self-identifying activities.

When we were being moved out of the hills, children and furniture went first. Then we took clothes, quilts, and rugs. My husband and I went last. He had a team of oxen. In the wagon, there was food just in case. I took our cow so we could get through the beginnings. In the city, it was all useless, 


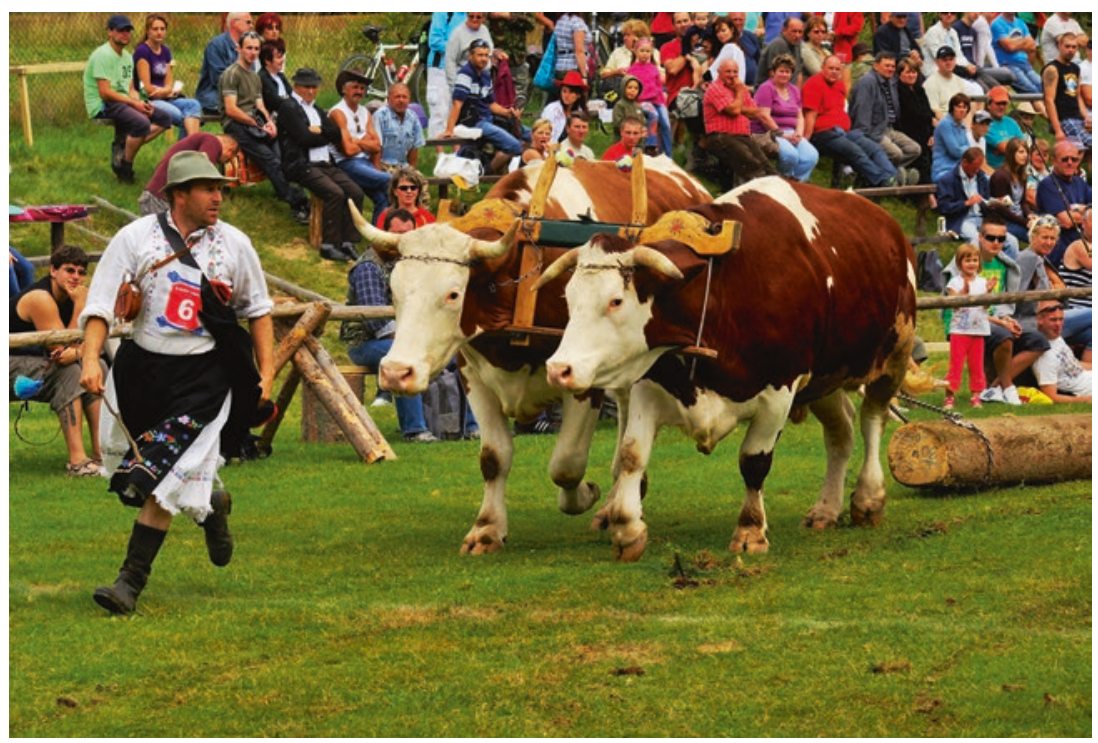

Fig. 5 Symbolic procession representing the vanishing cattle-breeding tradition among Vrchári. (This image used with permission of Vojtech Ilčík)

we had to start all over. (Vrchár female, 82 years, interview, 2018, trans. Ivan Murin)

New generations of Vrchári suffer from a reduced tolerance of very high amounts of milk in their diet. Children are seen with lactose intolerance, which was only rarely seen among older generations of Vrchári. In terms of pragmatic arguments, this leads us to consider relatively recent findings about transgenerational epigenetic inheritance-the influence of a person's environment on their behavior, their physiological processes, and those of future generations as well. An oft-cited example of such biocultural evolution is human digestion of lactose (Itan et al., 2010). ${ }^{8}$

\footnotetext{
${ }^{8}$ The ability to digest lactose past infancy is apparently caused by a single mutation in the regulatory sequence of the dominant gene that governs this process (Lukito et al., 2015). This mutation is more prevalent in areas with a long-established tradition of raising cattle and consuming dairy products (Gerbault et al., 2011). This fact may prematurely lead us to the conclusion that selective pressures governed by culture are much stronger than others, which can be explained by the ability of a cultural trait to, through social learning, spread much
} 
Typically, the ability to digest dairy products is higher in populations with a long cultural history of consuming, processing, and preserving milk. Thus, one pragmatic argument for environmental sustainability is literally rooted in the foothill pastures of northern Malohont. A symbolic argument, on the other hand, is embodied in the animals themselves: cows and oxen as symbols of vitality.

\section{Discussion}

One of the main sustainability changes around the world are changes in the generational structure of local populations, the phenomenon of aging, and other demographic indicators. In this case we have outlined secondary social-ecological processes which started and developed in parallel with these changes in peripheral areas in Slovakia (Mládek et al., 2006). Through anthropological research, we can recognize what impact this phenomenon has on long-established communities and its implications for sustainability (Depoe, 2007; Cox, 2006). With the disappearance of many local cultures, or in better cases, their preservation by museums, we have lost examples of diversity and bases for sustainability. Examples of adaptations have a cultural value when we can verify their sustainability features in the living system. Logic, thinking, and decision making in everyday interactions with the environment form an alternative epistemological basis.

Recent discussions on the argumentation used in environmental communication (Anderson, 2015; Besely, 2015; Cox, 2015) further support the efforts of anthropologists to broadcast "native voices" from their fieldwork. Voices from field research are met with understanding wherever change-oriented research is problem-driven and targets processes of social change. However, dilemmas still persist as to how to seriously reflect on native knowledge in the broad causality of nature and culture. The dilemma presented by a joint team of researchers from Uppsala and Exeter (Joosse et al., 2020) is the issue of the acceptance of co-producing (sustainability) knowledge. They point out (p. 7) that, in their study, "hierarchical and bureaucratic logic pushed most ambitions and ideas for future development aside," which is also observable in the present study and

faster than a genetic mutation; as more and more individuals adopt the trait, the genes that encourage it are subjected to ever more intensive pressure (Švorcová \& Kleisner, 2017, p. 353). 
beyond. On the other hand, we have encouraging findings on the acceptance of native knowledge where policymakers are increasingly acknowledging the importance of native knowledge (indigenous knowledge, TEK) for understanding and adapting to environmental change (Armitage et al., 2011; Raymond-Yakoubian \& Daniel, 2018; Wheeler et al., 2020).

In interviews with members of local communities, we discovered local voices illustrating what communication arguments are used in activities to maintain their culture. Members of revitalized Vrchár communities are aware of the need to foster cross-generational cultural transfer. They create new incentives to preserve it and have set up a series of activities aimed at local stakeholders and their own community members, as well as visitors to revitalized areas. The conservation of generative transmission processes is considered to be a method of preventing generational amnesia of TEK (Cantrill, 2010, p. 29). Seasonal events have increased public interest. Vrchári have been able to expand regional education to include teaching schoolchildren about Vrchár culture, and they run regular workshops for the potential new generation of Vrchári.

"What is the cultural, symbolic, and pragmatic value of the increased activism of the last generations of depopulating European peripheries?" is a question often faced in environmental communication. In applying the findings of anthropologists, environmental communication scholars work with the thesis that effective environmental communication constitutes a trigger for implementing aid to stabilize or revitalize culture (Schwarze, 2007). Its success is based on authentic experiences, their distinctive epistemological origins (Stoffle \& Minnis, 2008), and symbolic argumentation. Based on the research in Slovakia, we contend that effective environmental communication is not based on the absolute number of argumentative communicators. The value that will always appear in a reflective dialogue is the long-term, deep, everyday experience of community members with their co-adaptation to a specific environment.

Acknowledgments This chapter and the research it is based on were supported by public funding from the Slovak Arts Council as part of the project The Presentation of Research, Condition and Protection of Traditional Culture During the European Year of Cultural Heritage, No. 18-460-01673, Slovak Ministry of Culture. 


\section{REFERENCES}

Adger, N., \& Vincent, K. (2005). Uncertainty in adaptive capacity. Comptes Rendus Geosciences, 337(4), 399-410.

Anderson, A. (2015). Reflections on environmental communication and the challenges of a new research agenda. Environmental Communication, 9(3), 379-383. https://doi.org/10.1080/17524032.2015.1044063

Appadurai, A. (1986). The social life of things: Commodities in cultural perspective. University Press.

Armitage, D., Berkes, F., Dale, A., Kocho-Schellenberg, E., \& Patton, E. (2011). Co-management and the co-production of knowledge: Learning to adapt in Canada's Arctic. Global Environmental Change, 21(3), 995-1004.

Babai, D., \& Molnár, Z. (2014). Small-scale traditional management of highly species-rich grasslands in the Carpathians. Agriculture Ecosystems \& Environment, 182(1), 123-130.

Berger, P., \& Luckmann, T. (1966). The social construction of reality: A treatise in the sociology of knowledge. Doubleday.

Berkes, F. (1993). Traditional ecological knowledge in perspective. In J. Inglis (Ed.), Traditional ecological knowledge: Concepts and cases (pp. 1-9). Canadian Museum of Nature/International Development Research Centre.

Berkes, F., \& Folke, C. (2002). Back to the future: Ecosystem dynamics and local knowledge. In L. Gunderson (Ed.), Panarchy: Understanding transformations in human and natural systems (pp. 122-137). Island Press.

Besely, J. (2015). Making environmental communication work: Creating useful guidance. Environmental Communication, 9(3), 398-403. https://doi.org/1 $0.1080 / 17524032.2015 .1044006$

Cantrill, J. G. (2010). Measurement and meaning in environmental communication studies: A response to Kassing. Johnsson, Kloeber, and Wentzel, 4(1), 22-36.

Cavalli-Sforza, L. L., \& Feldman, M. W. (1981). Cultural transmission for a continuous trait. In Cultural transmission and evolution: A quantitative approach (pp. 346-351). Princeton University Press.

Cocks, M. (2006). Bio-cultural diversity: Moving beyond the realm of indigenous and local people. Human Ecology, 34(2), 185-200.

Colloff, M., Wise, R., Palomo, I., Lavorel, S., \& Unai, P. (2020). Nature's contribution to adaptation: Insights from examples of the transformation of socialecological systems. Ecosystems and People, 16(1), 137-150.

Cox, R. (2006). Environmental communication and the public sphere. SAGE.

Cox, R. (2015). Scale, complexity, and communicative systems. Environmental Communication, 9(3), 370-378.

Depoe, S. (2007). Environmental communication as nexus. Environmental Communication, $1(1), 1-4$. 
Ethnographic Institute of the Slovak Academy of Sciences. (1994). Ethnographic atlas of Slovakia: Translations and explanations of texts. VEDA.

Eurostat. (2019). https://ec.europa.eu/eurostat

Feranec, J., Jaffrain, G., Soukup, T., \& Hazeu, G. (2010). Determining changes and flows in European landscapes 1990-2000 using CORINE land cover data. Applied Geography, 30(1), 19-35.

Fernández-Giménez, M., \& Fillat Est, F. (2012). Pyrenean pastoralists' ecological knowledge: Documentation and application to natural resource management and adaptation. Human Ecology, 14(2), 287-300.

Folke, C. (2004). Traditional knowledge in social-ecological systems. Ecology and Society, 9(3), [online]: http://www.ecologyandsociety.org/vol9/iss3/art7/

Gardner, A. (2017). The purpose of adaptation. Interface Focus, 7(5), Epub 2017 Aug 18.

Gerbault, P., Liebert, A., Itan, Y., Powell, A., Currat, M., Burger, J., Swallow, D. M., \& Thomas, M. (2011). Evolution of lactase persistence: An example of human niche construction. Philosophical Transactions: Biological Sciences, 366(1566), 863-877.

Gilck, F., \& Poschlod, P. (2019). The origin of alpine farming: A review of archaeological, linguistic and archaeobotanical studies in the Alps. The Holocene, 29(9), 1503-1511.

Gómez-Baggethun, E., \& Reyes-García, V. (2019). Reinterpreting change in traditional ecological knowledge. Human Ecology, 41(4), 643-647.

Gömöry, D., Dovčiak, M., Gömöryová, E., Hrivnák, R., Janišová, M., \& Ujházy, K. (2006). Demecological, synecological and genetic aspects of colonization of nonforest areas with forest trees. Technická Univerzita vo Zvolene.

Horton, C., Hall, D., Gilbertz, S., \& Peterson, T. (2017). Voice as entry to agriculturalists' conservationist identity: A cultural inventory of the Yellowstone River. Environmental Communication, 11(5), 609-623.

Huba, M. (1997). Kopaničiarske osídlenie, životné prostredie a trvalo udržateľný spôsob existencie [Dispersed Kopanitse settlement, environment and sustainable way of existence]. Životné prostredie, 31(3), 61-66.

Ingold, T. (2000). The perception of the environment: Essays on livelihood, dwelling and skill. Routledge.

IPBES. (2019, December 20). Global assessment report on biodiversity and ecosystem services. https://ipbes.net/global-assessment

Itan, Y., Jones, B. L., Ingram, C. J., Swallow, D. M., \& Thomas, M. G. (2010). A worldwide correlation of lactase persistence phenotype and genotypes. $B M C$ Evolutionary Biology, 10(1), 1-11.

Janšák, Š. (1929). Príspevok k štúdiu osídlenia Slovenska [A contribution to the study of the settle colonize of Slovakia]. Sbornik muzeálnej slovenskej spoločnosti, 23, 93-111. 
Joosse, S., Powell, N., Bergeå, H., Böhm, S., Calderón, C., Caselunghe, E., Fischer, A., Grubbström, A., Hallgren, L., Holmgren, S., Löf, A., Nordström Källström, H., Raitio, K., Senecah, S., Söderlund, C., Von Essen, E., Westberg, L., \& Westin, M. (2020). Critical, engaged and change-oriented scholarship in environmental communication: Six methodological dilemmas to think with. Environmental Communication, 14(6), 758-771. https://doi.org/10.108 $0 / 17524032.2020 .1725588$

Kandert, J. (2007). Local history and social networks in everyday political practice: The case of Central Slovakia and Southern Moravia. In K. Roth (Ed.), Soziale Netzwerke und soziales Vertrawen in den Transformationsländern: ethnologische und soziologische Untersuchungen (pp. 213-218). Lit Verl.

Kanianska, R., Kizeková, M., Nováček, J., \& Zeman, M. (2014). Land-use and land-cover changes in rural areas during different political systems: A case study of Slovakia from 1782 to 2006. Land Use Policy, 36, 554-566.

LeCompte, M. D., \& Schensul, J. J. (2013). Analysis and interpretation of ethnographic data. A mixed methods approach. AltaMira Press.

Lieskovský, J., Bezák, P., Špulerová, J., Lieskovský, T., Koleda, P., Dobrovodská, M., Bürgi, M., \& Gimmi, U. (2015). The abandonment of traditional agricultural landscape in Slovakia: Analysis of extent and driving forces. Journal of Rural Studies, 37, 75-84.

Lindenfeld, L. A., Hall, D. M., McGreavy, B., Silka, L., \& Hart, D. (2012). Creating a place for environmental communication research in sustainability science. Environmental Communication: A Journal of Nature and Culture, $6(1), 23-43$.

Lukito, W., Malik, S., Surono, I., \& Wahlqvist, M. (2015). From "lactose intolerance" to "lactose nutrition". Asia Pacific Journal of Clinical Nutrition, 1, 1-8.

MacDonald, D., Crabtree, J., Wiesinger, G., Dax, T., Stamou, N., Fleury, P., Gutierrez Lazpita, J., \& Gibon, A. (2000). Agricultural abandonment in mountain areas of Europe: Environmental consequences and policy response. Journal of Environmental Management, 59(1), 47-69.

McDonnell, M. J., \& Pickett, S. T. (1993). Humans as components of ecosystems: The ecology of subtle human effects and populated areas. Springer-Verlag.

Mládek, J., Kusendová, D., Marenčáková, J., Podolák, P., \& Vaňo, B. (2006). Demografická analýza Slovenska [A demographic analysis of Slovakia]. Univerzita Komenského.

Murin, I., \& Kandert, J. (2018). The daily rhythm of the villager of Central Slovakia: Comparative study of the chronological ethnography of four families from the Sihla plain in 1967-2017. Ceský lid, 105(1), 3-23.

Navarro, L., \& Pereira, H. (2012). Rewilding abandoned landscapes in Europe. Ecosystems, 15, 900-912. 
Novák, J., Podolák, J., Zuskinová, I., \& Margetín, M. (2014). Po stopách valachov $v$ Karpatoch [Following the footsteps of the Vlachs in the Carpathians]. Brno: Tribun EU.

Petrovič, F. (2006). Changes of the landscape with dispersed settlement. Ekológia, 25(1/2006), 201-211.

Priečko, M. (2015). Socioekonomické perspektívy rozptýleného osídlenia na Slovensku (komparácia lokalit Málinec, Nesluša a Valaská Belá) [Social and economic perspectives of dispersed settlement in Slovakia (based on the ethnological comparison of villages Málinec, Nesluša and Valaská Belá)]. Trnava: Univerzita sv. Cyrila a Metoda.

Raymond-Yakoubian, J., \& Daniel, R. (2018). An Indigenous approach to ocean planning and policy in the Bering Strait region of Alaska. Marine Policy, 97, 101-108.

Ruddle, K. (1993). The transmission of traditional ecological knowledge. In J. Inglis (Ed.), Traditional ecological knowledge: Concepts and cases (pp. 17-32). Canadian Museum of Nature/International Development Research Centre.

Sandhu, H., \& Wratten, S. (2013). Ecosystem services in farmland and cities. In S. Wratten, H. Sandhu, R. Cullen, \& R. Costanza (Eds.), Ecosystem services in agricultural and urban landscapes (pp. 3-11). Wiley-Blackwell.

Schwarze, S. (2007). Environmental communication as a discipline of crisis. Environmental Communication, 1(1), 87-98.

Sjölander-Lindqvist, A., \& Sandström, C. (2019). Shaking hands: Balancing tensions in the Swedish forested landscape. Conservation and Society, $17(4), 319-330$.

Špulerová, J., Dobrovodská, M., Štefunková, D., Piscová, V., \& Petrovič, F. (2016). History of the origin and development of the historical structures of traditional agricultural landscape. Historický časopis, 64(1), 109-126.

Steward, J. H. (1955). Theory of culture change: The methodology of multilinear evolution. University of Illinois Press.

Stoffle, R., \& Minnis, J. (2008). Resilience at risk: Epistemological and social construction barriers to risk communication. Journal of Risk Research, $11,55-68$.

Stoffle, R. W., Stoffle, B. W., \& Sjölander-Lindqvist, A. (2013). Contested time horizons. In A. Bond, A. Morrison-Saunders, \& R. Howitt (Eds.), Sustainability assessment: Pluralism, practice and progress (pp. 51-67). Routledge.

Stoffle, R. W., Toupal, R., \& Zedeno, N. (2003). Landscape, nature, and culture: A diachronic model of human-nature adaptations. In H. Selin (Ed.), Nature across cultures: Views of nature and the environment in non-Western cultures (pp. 97-114). Kluwer Academic Publishers.

Švecová, S. (1975). Kopanicové sídla a dedina. Národopisná štúdia o spoločenských vzłahoch medzi obyvatelmi jednej slovenskej obce. Univerzita Karlova. 
Švorcová, J., \& Kleisner, K. (2017). Jak s námi žije minulost: Epigenetika jako pojítko mezi kulturní a biologickou evolucí [How the past lives with us: Epigenetics as a link between cultural and biological evolution]. In L. Ovčáčková (Ed.), O piovodu kultury. Biologické, antropologické a historické koncepce kulturní evoluce [About the origin of culture: The biological, anthropological and historical concepts of cultural evolution] (pp. 349-371). Prague: Academia.

The Permanent European Conference for the Study of the Rural Landscape. (n.d.). http://www.pecsrl.org/index.html

Tindall, A. (1976). Theory in the study of cultural transmission. Annual Review of Anthropology, 5, 195-208.

Wheeler, H., Danielsen, F., Fid, M., Hausner, V., Horstkotte, T., Johnson, N., Lee, O., Mukherjee, N., Amos, A., Ashthorn, H., Ballari, Ø., Behe, C., BretonHoneyman, K., Retter, G., Buschman, V., Jakobsen, P., Johnson, F., Lyberth, B., Parrott, J., Pogodaev, M., Sulyandziga, R., \& Vronski, N. (2020). The need for transformative changes in the use of Indigenous knowledge along with science for environmental decision-making in the Arctic. People and Nature, $2,544-556$.

Open Access This chapter is licensed under the terms of the Creative Commons Attribution 4.0 International License (http://creativecommons.org/licenses/ by $/ 4.0 /)$, which permits use, sharing, adaptation, distribution and reproduction in any medium or format, as long as you give appropriate credit to the original author(s) and the source, provide a link to the Creative Commons licence and indicate if changes were made.

The images or other third party material in this chapter are included in the chapter's Creative Commons licence, unless indicated otherwise in a credit line to the material. If material is not included in the chapter's Creative Commons licence and your intended use is not permitted by statutory regulation or exceeds the permitted use, you will need to obtain permission directly from the copyright holder.

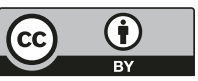

